\title{
The Twentieth-Century Secularization of the Sinograph in Vietnam, and its Demotion from the Cosmological to the Aesthetic
}

\author{
John Duong Phan* \\ Rutgers University \\ john.phan@rutgers.edu
}

\begin{abstract}
This article examines David Damrosch's notion of "scriptworlds" - spheres of cultural and intellectual transfusion, defined by a shared script - as it pertains to early modern Vietnam's abandonment of sinographic writing in favor of a latinized alphabet. The Vietnamese case demonstrates a surprisingly rapid readjustment of deeply held attitudes concerning the nature of writing, in the wake of the alphabet's meteoric successes. The fluidity of "language ethics" in early modern Vietnam (a society that had long since developed vernacular writing out of an earlier experience of diglossic literacy) suggests that the durability of a "scriptworld" depends on the nature and history of literacy in the societies under question.
\end{abstract}

\section{Keywords}

Vietnamese literature - Vietnamese philology - Chinese philology - script reform language reform - early modern East Asia/Southeast Asia

\section{Introduction}

In 1919, the French-installed emperor Khải Định permanently dismantled Vietnam's civil service examinations, and with them, an entire system of political

* I would like to thank Wynn Wilcox, Nguyễn Tuấn Cường, Tuna Artun, and Jack Chia for their valuable help and input. All errors are my own. 
selection based on proficiency in Literary Sinitic. ${ }^{1}$ That same year, using a controversial latinized alphabet called Quốc Ngũ (lit. "National Language” 國語), one Vietnamese intellectual declared that "today, our nation must learn Quốc Ngũ letters and French writing, but Chinese characters should also not be abandoned."2 Despite his plea, all forms of sinographic writing would effectively disappear over the next two decades or so, replaced by Quốc Ngữ. Today, Vietnam is the only culturally East Asian nation that uses a Latin alphabet.

David Damrosch ("Scriptworlds") draws attention to the role of script as a vehicle for cultural and literary transfusion, and raises the question of how script may define or constrain that transfusion. In one example, Damrosch describes how the circulation of the epic Gilgamesh was strikingly restricted to societies employing Cuneiform, and that despite evidence of some exposure to Gilgamesh among Hellenistic peoples (using a Phoenician derived alphabet) later in history, no direct literary transfusion appears to have obtained (Damrosch 198). In another, contrastive example, Damrosch describes the "grammatological sovereignty" with which Icelandic poets such as the 14th century Snorri Sturluson experimented with Latin and Christian motifs, freely hybridizing them with Pagan themes associated with a runic past (209-213). Damrosch's work casts focus on to script as an important determiner of cultural geography, alongside shared language, religious affiliation, or political control. While I agree with the importance of script as both a vehicle and constraint of cultural transfusion, I suggest that any understanding of that importance must account for the nature and history of literacy, in the cultures under question. The two cases cited above, for example, seem to represent vastly different linguistic conditions of exchange. Damrosch's otherwise illuminating notion of "scriptworlds," unfortunately does not to consider the work Sheldon Pollock has done on arguably universal principles of vernacularization, in diglossic societies long accustomed to the presence of a prestigious "cosmopolitan" language, distinct from the predominant spoken form. ${ }^{3}$ Furthermore, a glance

1 I follow the conventional translation of 文言文 as "Literary Sinitic," which I prefer to both "Literary Chinese" (a term that occludes the importance of this language to Korea, Japan, and China), and "Classical Chinese," which properly only refers to the language of the Zhou Dynasty Classics, composed in the first millennium BCE. Literary Sinitic may be understood as the high, literary language of a cosmopolitan East Asia (functionally analogous to Latin or Sanskrit in Europe and South Asia respectively).

2 Phạm Huy-hổ: "Nước ta ngày nay nên học chữ quốc ngữ và chữ Pháp, mà chữ Hán cũng không nên bỏ" (Phạm 416).

3 See Sheldon Pollock. The Language of the Gods in the World of Men. Berkeley: University of California Press, 2006. 
at modern "switching" from one script to another (as occurred in Soviet-era Chechnya, under Atatürk in early 2oth century Turkey, and as discussed in this article, at the end of colonial rule in 1920 Vietnam), suggests a culturally and politically charged, frequently controversial process, which nevertheless does not seem to initiate a new cultural hegemony based on the adopted script, nor necessarily abort the circulation of texts written in the rejected script. ${ }^{4}$ I suggest, therefore, that a particular society's engagement with script as a cultural phenomenon is meaningfully correlated with whatever stage of literacy that society has achieved at the point of contact. A society developing patterns of literacy for the first time in a foreign script — and language — is likely to absorb a broad spectrum of cultural, intellectual, religious, and/or political attitudes as a bundled package, and is less likely to demonstrate the kind of "grammatological sovereignty" that Damrosch attributes to the Icelandic case. By contrast, a literate, and critically, vernacularized society that "switches" from one script to another has already developed categories for language and writing that are innately fluid, and which dilute the power of a new script to determine broader cultural or intellectual values. Thus while such a transition may ignite great political and intellectual controversy (as I will describe in the Vietnamese case here), it may not define the same kinds of durable boundaries to cultural transfusion that the initial adoption of a script (or "entry" into a scriptworld) might engender. ${ }^{5}$

This model would certainly explain the Vietnamese case. Like the vast majority of societies in the history of the world, the Vietnamese first experienced literacy in a language different from their predominant spoken form. For over a thousand years, the only language read or written in the area of northern Vietnam was Literary Sinitic. This condition obtained naturally as the result of Han colonization of the region in the last century вСE, and would only change after the disintegration of Tang control eleven centuries later. The Vietnamese vernacular was first cast into a systematic written form some time in the early 2nd millennium CE. That system, called Chũ Nôm (宁字喃, 字喃, or 字喃; hereafter, "Nôm"), may be understood as an extension of the sinographic script designed to represent the Vietnamese lexicon. No substantial innovation of, or deviation from the basic six grahs 六書 principles of sinographic writing was

4 Though certainly, there were intellectual casualties accrued through the abandonment of a sinographic education.

5 Assuming reasonable continuity in the society in question. I would add here that the force of script to determine the nature of cultural transfusion in cases of diglossic vernacularization likely derives from a culturally mandated education in the cosmopolitan language, to which the script promised access. 
attempted. ${ }^{6}$ In fact, a conscious effort to avoid a fully phonographic system, in favor of more "semantosyllabic" 形聲 characters (combining a semantic and a phonetic element) arose, as Nôm gained in popularity over the 17th-19th centuries. Thus, Vietnam's initial experience of literacy was shaped by Literary Sinitic, and its development of a vernacular script likewise followed the mold of Chinese characters.

This history is shared, in broad strokes, with Korea and Japan as well, and the consumption and production of Literary Sinitic texts formed the basis for what Ross King has called a "Sinographic Cosmopolis."7 If, as Damrosch suggested, the adoption of a script meant the adoption of "a whole complex of values, assumptions, and traditions," then King's "Sinographic Cosmopolis" describes the intellectual and literary space self-consciously shared betwen members of the sinographic scriptworld. This Sinographic Cosmopolis was built on a concept of Chinese writing as the projection of a cosmologically ordered pattern (Viet. văn 文), believed to be interpreted and then transmitted by the classical sages (hiền nhân 賢人, "worthy men"; or the slightly broader term thánh hiền 聖賢, "sages and worthies"), whose wisdom in turn laid the foundation for society, governance, and culture. This concept served as a kind of cosmological underpinning to the practice of writing, one tied not merely to the canon of literature written in Literary Sinitic, but also to the sinograph itself, as an emblem and manifestation of $\nu a ̆ n$. Thus, the Japanese went to great lengths to maintain the illusion of pure sinographic writing through methods such as kundoku 訓読, while vernacular Korean did not eclipse Literary Sinitic until the modern era (despite the innovation of a uniquely elegant alphabet in the form of Hangul).

In Vietnam, it was not until the aforementioned abandonment of the civil service examinations in 1919, and the rapid adoption of the latinized alphabet known as Quốc Ngũ over the 1920s, that the vernacular finally came to displace Literary Sinitic as the written language of choice. Although blindingly fast, and ruthlessly thorough in its displacement of sinographic writing, the alphabet predictably clashed with deeply rooted concepts of $v a ̆ n$ as the basis of humanity, learning, and nature. As described below, the question of abandoning sinographic writing struck an almost religious nerve, while the adoption of the Quốc ngũ alphabet was perceived by some as a harbinger of the final eradication of Vietnamese language and culture.

6 Please see the full version of this article for a description of the six graphs.

7 Ross King coined this term for a series of international workshops beginning in the summer of 2012, in response to Sheldon Pollock's revolutionary work on the "Sanskrit Cosmopolis" of South Asia. 
Yet despite these fears, the alphabet displaced both Hán and Nôm writing within a couple decades. Vietnamese culture was not eradicated, and indeed, Vietnamese vernacular literature flourished in ways it never had before. Most significantly, the adoption of the Latin alphabet failed to lock the Vietnamese into a new cultural space defined by Roman letters, as the initial adoption of sinographic writing arguably had. Instead, what we find is a sort of measured cognitive dissonance evolving in the intellectual discourse, one that increasingly secularized the concept of writing until the adoption of an alien script was leeched of cosmological significance. This curious, rationalizing process is best observed in a series of script experiments rapidly produced just as the alphabet was coming into its own. This article will describe these script experiments in detail, and demonstrate how their increasingly secular conceptualizations of writing, in fact express an immunity to membership in a new "scriptworld," despite the salient adoption of a new and prestigious script.

Section 1 briefly examines revisits the long-held reverence for the sinograph. Section 2 then turns to three script experiments, published in 1929, 1932, and 1933 respectively, which articulate a rapid reorientation of values regarding script. Finally, Section 3 discusses these texts as an exemplification of the "secularization" of the sinograph in Vietnam over time, and considers what such a process might reveal about the nature of scriptworlds in a modern, multiliterate world.

\section{Vietnamese Reverence for a "Sagely Script"}

By the mid 16oos, French, Portuguese, and Italian missionaries had already developed what would later be known as the Quốc Ngũ alphabet for Vietnamese. ${ }^{9}$ Yet despite the phonographic accuracy and easy learnability of the alphabet, it would remain, for the next 350 years or so, restricted to Catholic circles and virtually ignored by educated Vietnamese. Instead, Vietnamese literati continued to compose primarily in Literary Sinitic, and when they did indulge in vernacular writing, they preferred the sinographic script known as Chữ Nôm. There were thus two layers of sinographic preference that insulated the Vietnamese from latinized writing: 1) a devotion to Literary Sinitic as a cosmopoli-

8 Due to space constraints, this section has been greatly abbreviated. Please see the complete version of this article for a fuller treatment of these issues.

9 Alexandre de Rhodes (1591-166o) published a Vietnamese-Portuguese-Latin dictionary using the alphabet in 1651 . 
tan language (over any vernacular language and script); and 2) a preference for Nôm, when engaging in vernacular composition.

This devotion to the sinograph was rooted in a conceptualization of true writing as the invention of the ancient Sages-exemplary figures who fundamentally improved human society in one manner or another. The association of script with these founders of civilization is clearly expressed in a 17th century Sino-Vietnamese dictionary, entitled Explication of the Guide to Jeweled Sounds 指南玉音解義 (Viet. Chi nam ngọc âm giải nghĩa). The 2nd preface of the dictionary opens as follows: ${ }^{10}$

Lo, when the positions of the Three Fundamental Powers were established, all was a jumbled vastness, [and] men and phenomena were difficult to name ... The numerous categories were extremely complex. With neither writing nor [the wherewithal to] indicate names, the multitude of ignorants found it difficult to discern [things]. Thus, since ancient times the Sages have established the side to indicate meaning, thereby rectifying the speaking of names.

my translation, manuscript AB372

夫, 三才定位, 盖混茫, 人物難名 ... 庶類甚繁。非文字亦非指名, 群蒙難識。夫，自古聖人立傍說義，以正言名。

The idea of "rectifying names" is an oblique reference to the Analects 13:3, where Confucius discusses the importance of proper language to the welfare of the state; but here it also functions as a description of semantosyllabic writingi.e. the exemplary sinograph — with semantic radicals placed "to the side" of a phonetic base. The human condition is thus described as fundamentally improved by the sagely invention of sinographic writing.

Given this deeply held reverence for a "sagely scipt," it is not surprising that many early-modern intellectuals viewed the abandonment of Chinese characters as a threat to the civilized state. In 1918, the Grand Secretariat of the Eastern Hall, Tôn Thất Tổ, issued the following statement in protest to Emperor Khải Định's proposal to abandon Chinese characters:

For hundreds and thousands of years, our nation has continued to teach and learn through books of Chinese characters. We use them to transmit moral principles, and to illuminate proper relationships. Chinese charac- 
ters have become a golden compass for the people of our nation, and thus I must beg to argue and urge for their maintenance and safeguarding, and that they may not be abandoned arbitrarily.

my translation; NGUYỄ N, 355

Nước ta từ hàng trăm nghìn năm nay vẫn giảng dạy học tập bằng sách vở chữ Hán, dùng để chuyền tải đạo lý, làm tỏ luân thường. Chữ Hán đã trở thành kim chỉ nam cho người nước ta, vậy phải xin bàn bạc thương lượng cho duy trì giữ lại mà không thể bỗng dưng phế bỏ đi được.

For men such as Tôn Thất Tổ, civilized society was inextricably bound to sinographic culture. Abandoning Chinese writing meant abandoning the wisdom of the Sages and Worthies, a critical blow to Vietnamese culture in an already compromised time (i.e. of colonization). ${ }^{11}$ Very similar sentiments were expressed in contemporary Turkey, also in the face of adopting the Latin alphabet. In 1923 the Turkish general Kâzim Karabekir (1882-1948) declared that adopting the Latin alphabet would place "a splendid weapon in the hands of all Europe; they will declare to the Islamic world that the Turks have accepted the foreign writing and turned Christian ... [t] he diabolical idea with which our enemies are working is precisely (this)" (Lewis 32). Like Karabekir, Tôn Thất Tổ perceived script as the bulwark of a society under siege, and considered the alphabet to be the vanguard of a cultural invasion.

\section{The Secularization of the Sinograph}

But despite the vehemence of such protests, the alphabet proved immensely popular, and over the 1920's and 1930's, enabled Vietnamese to displace both Literary Sinitic and French, as incumbent and potential "national languages" respectively. The rapid spread of the alphabet continued to stimulate a philosophical debate among the Vietnamese, which, in inverse proportion to the

11 Here, as in the Emperor's response to Tôn Thất Tổ discussed below, "Chinese characters" refers both to script and Literary Sinitic education in general. The idea that script or language was somehow tied to the welfare of the state (itself a reflection of Confucius' sentiments in the Analects 13: 3), is critically expressed in a 1921 script experiment called New Characters for the Nation's Sounds 指南玉音解義, and it is precisely this notion that evaporates in the following decade or so. For a discussion of this important text, please see the full version of this article. 
success of Quốc Ngũ̃, rapidly decreased in urgency and consequence. Marr (1981) briefly lists three experiments with script that were published over the late 1920 and early 1930s. When examined against the reverence for sinographic writing discussed above, these script experiments articulate an increasingly mundane attitude toward sinographic writing that indirectly rationalizes the adoption of Quốc Ngũ (post factum), and suggests a disintegration of the meaningfulness of scriptworld boundaries.

\section{A Technical Objection to the Alphabet}

The earliest "post-alphabetical" script experiment, published in 1929 and entitled Viet Characters: A Style of Writing Annamese (Việt Tự: Một lối viết tiếng An Nam), already exhibits a vastly different attitude toward non-sinographic writing than suggested by, for example, Tôn Thất Tổs impassioned protest discussed above. Most saliently, the preface was written in French rather than Literary Sinitic - a clear token of French education. In fact, the author (Vi HuyềnĐắc, 1899-1976) quickly explains that his main complaint about Quốc Ngũ̃ is merely that it cannot elegantly represent the rich vocalic and tonal inventories of the Vietnamese language:

The Latin alphabet can only give us 12 vowels, but Annamese, which has a great phonic richness, requires sixty others. To fill in this lacuna, one must resort to the subterfuge of the five tonal accents. Thus (lit. et, "and") of twelve vowels, one has made 72 , which combine with the consonants to form almost all the syllables of the language.

my translation; VI, A

L'Alphabet latin ne peut nous donner que 12 voyelles mais l' annamite qui a une grande richesse phonique en demande soixante autres. Pour combler cette lacune, on a eu recours au subterfuge des cinq accents toniques. Et, de 12 voyelles on en fait 72, qui combinées aux consonnes forment presque toutes les syllables de la langues.

In almost the same breath, however, Vi also admits his own admiration for Quốc Ngữ:

Certainly, this amiable exchangeability [of vowels] is not devoid of ingenuity, and for 50 years, Latin Quốc Ngũ has provided palpable proof of its marvelous flexibility of adaptation.

my translation; VI, A 
Certes, cet affablement interchangeable n' est point dépourvu d'ingéniosité et depuis $5^{0}$ ans, le Quốc-Ngũ latin a donné une preuve palpable de sa merveilleuse souplesse d'adaptation.

Vi clearly respects the elegant design of the Latin alphabet. At the same time, since Latin letters were not uniquely created for Vietnamese, Vi suggests that they introduce undesirable inefficiencies that ought to be corrected: ${ }^{12}$

But the simplicity of the script and the shifting method of its use of accents induce us, at the least inattention, to grave and incredible confusions. Writing no longer possesses the immutable character that it has in other languages.

my translation; ibid.

Mais la simplicité du graphique et la façon mouvante de l'emploi de ces accents nous induisent, à la moindre inattention, en graves et incroyables confusions. L'écriture n'a donc plus ce caractère d'immuabilité qu'ont celles des autres langues.

Vi's system ultimately proposes discrete graphs for initial consonants and rimes (vowel + coda + tone), which may be combined in a way intriguingly reminiscent of the syllable-block arrangement of (alphabetic) Hangul. This results in 77 discrete syllabograms, similar in effect to Japanese Katakana or Hiragana (and it is tempting to speculate that either Korean or Japanese writing, as phonographic alternatives to the Latin alphabet, may have played some role in Vi's thinking here).

Regardless of the mechanics of his system, what is notably lacking in Viet Characters is the belief that writing carries any kind of cosmological significance. Of course, by 1929, Quốc Ngữ was already arguably more popular and widespread than Chũ̃ Nôm had ever been, a reality that was irreconciliable with a sinocentric view of script and culture. The question of script was still important to the Vietnamese at this point, but it had become transmuted into a matter of how most efficiently to represent the vernacular language. While Vi

12 Vi Huyền-Đắc had studied Literary Sinitic as a child, but soon shifted to a Quốc Ngữ education. He went on to become one of the most prolific contemporary playwrights of Vietnam. Although much of his work seemed to value pre-colonial customs and mores, he was also deeply influenced by French romanticism (as were many of his contemporaries), and we see this ambiguous relationship to French culture here in his response to Quốc ngũ as well. 


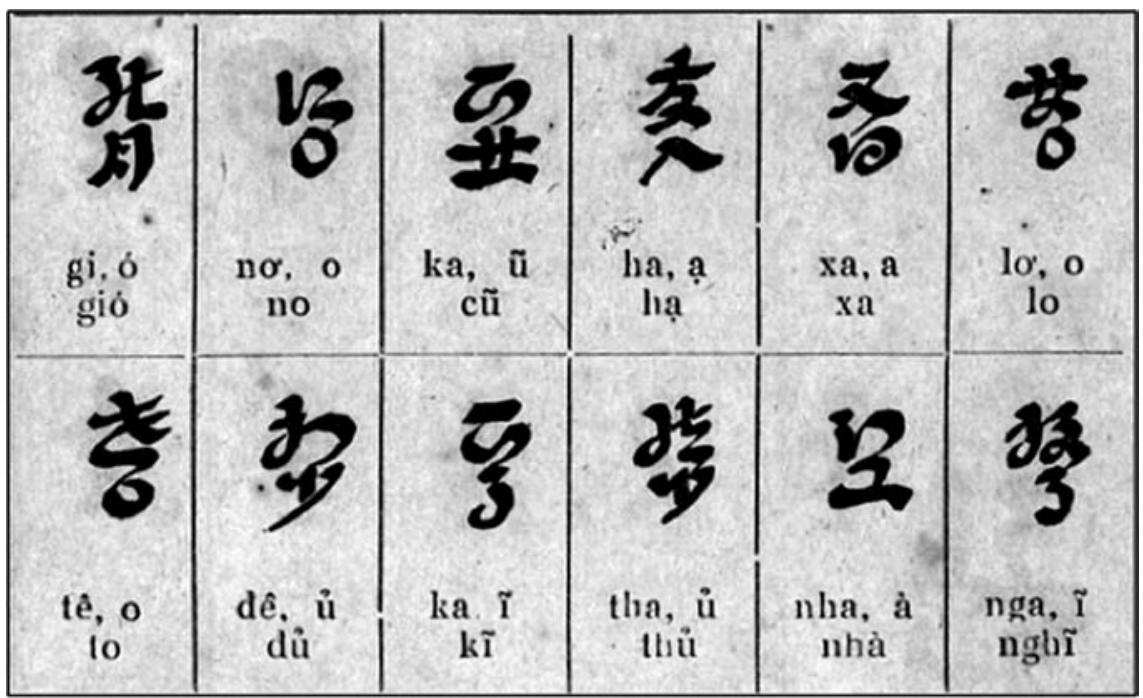

FIGURE 1 Some examples of consonant + vowel syllabograms, in the Viet Characters system

considered the alphabet intrinsically unsuited to the Vietnamese language, the issue for him was technical rather than cosmological.

\section{A Cultural Need or a Matter of Taste}

The other two texts, published in 1932 and 1933 respectively, take this "secularization" of the sinograph a step further, by relegating the need for some kind of sinography merely to the realm of ritual and aesthetics. Note first that the preface of the next script experiment, New Chũ Nôm (Chũ nôm mới) by Nguyễn Kinh-chu, is written neither in Literary Sinitic nor in French, but in Vietnamese Quốc Ngũ. In other words, Vietnamese-written in Quốc Ngũ —was now presumed as the language of intellectual expression (over both Literary Sinitic and French). For Nguyễn Kinh-chu, not even the technical compatibility of Quốc Ngũ was of any concern, but only its poor suitability to the cultural needs of the Vietnamese:

In our country, we have the custom of using couplets (in the form of calligraphic scrolls) to honor, joke with, bestow, congratulate, or bring offerings to dear friends and old companions. In the past, we used Chinese writing exclusively [for these purposes].

Today, fads have changed, French writing is in vogue, Quốc Ngũ is commonplace, and few people study Han writing. Han writing in this country is becoming more and more degenerate; in the future, it will be difficult to find anyone versed enough to write couplets or banners in 
Literary Sinitic. Surely then, one must write in the vernacular for couplets and banners.

But how does one write the vernacular so that it is convenient? Should we write in Quốc Ngũ or in old Chữ Nôm? One cannot write Quốc Ngữ vertically; as for old Chũ Nôm, each person writes it differently, and one must be versed in Chinese writing to be able to read it. Neither of these scripts is convenient.

my translation; NGUY ỄN, 1933, 3

Nước ta có tục dùng đối chướng để thờ, chơi, tặng, mừng, phúng, thân bằng cố hữu. Xưa nay toàn dùng hán-tự.

Ngày nay phong trào thay đổi, chữ pháp thịnh hành, chữ quốc ngữ phổ thông, ít người học hán-tự. Hán-tự ở nước ta càng ngày càng sui đối; sau này khó kiếm được người thông làm nồi bài đối, bài chướng bằng hán-văn. Tất phải dùng văn nôm vào đối chướng.

Song dùng văn nôm thì viết thế nào cho tiện? Viết bằng chữ quốc-ngữ hay chũ nôm cũ? Quốc ngữ không viết dọc được; chữ nôm cũ mỗi người viết một cách, mà phải thông hán-tự thì mới đọc viết được. Hai lối chữ ấy đều không tiện cả.

Fascinatingly, Nguyễn expresses not only a clearly secularized attitude on writing, but also a highly practical (and un-Confucian) attitude on ritual and culture in general. Calligraphy is a social necessity, but nothing more than that. Structurally, "New Chũ Nôm" simply consists of Han-Nôm radical-like forms that map more or less directly on to Quỗc Ngữ. There are a total of 39 characters, plus 5 diacritics for tone. The 39 characters are divided into 21 consonantal onsets and 18 vowels (including diphthongs, plus a system of alternation in order to capture finals). The five diacritics are for each tone, with high-level ngang tone unmarked. The consonants and tones are represented by radicals (consonants by left-side radicals and tones by radicals placed on top of the character), and the vowel/rime graphs occupy what would correspond to the phonetic graph in a traditional Han semantosyllabic character. Thus, when joined, "New Chũ̃ Nôm" looks indistinguishable from "old" Chũ Nôm, but—as the author proudly points out - it relies on knowledge of Quốc Ngữ, and anyone who knows Quốc Ngữ can teach himself to read and write the script in only twelve days or so (Nguyễn K.-C., p. 3). ${ }^{13}$ The author ends his preface by

13 "Thứ nôm mới này ... tỉnh thần theo quốc-ngũ̃, biết quốc ngữ rồi tự học lấy được; chỉ học độ 12 hôm là đọc và viết được." 


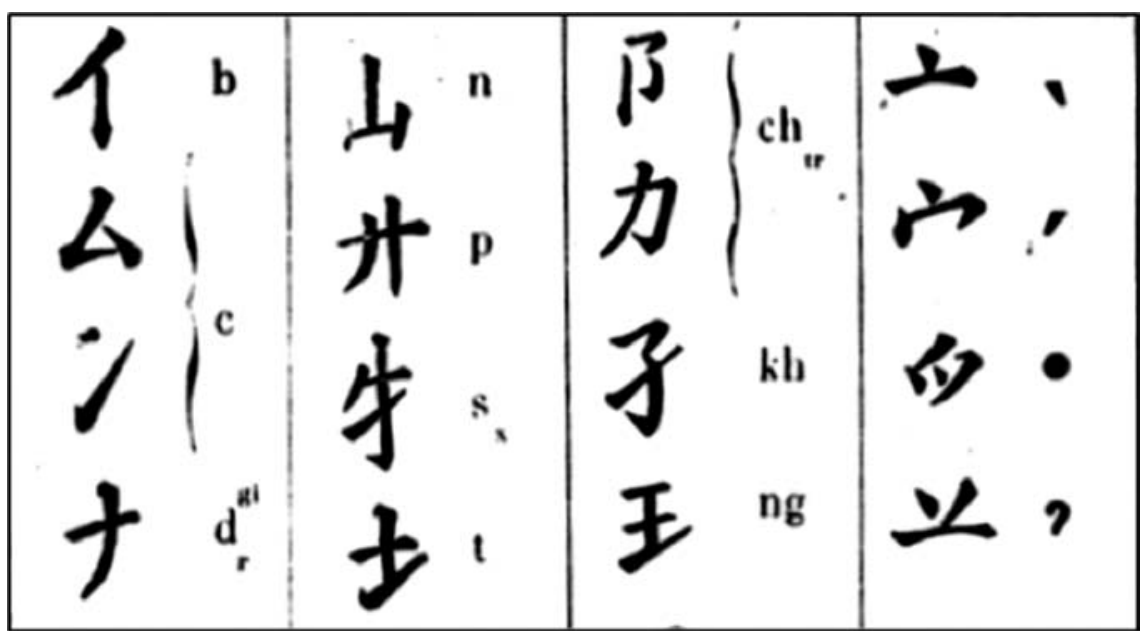

FIGURE 2 Sinographic radicals used for initial consonants, in New Chũ Nôm

emphasizing his harmless, depoliticized intent: "This New Nôm is a script for enjoyment ... When writing, one should use a brush for characters to be beautiful" (5). ${ }^{14}$

The last of the three script experiments, published in 1933 (only a year after New Chũ Nôm), is largely the same kind of project. Entitled Viet Characters, Quốc Ngũ displayed in Chinese characters (Chũ Việt, Quốc Ngũ lòi chũ Nho), the script was designed specifically for use in writing parallel calligraphic verses or couplets (câu đối). The system is quite similar to New Chũ Nôm, and consists of 24 initial consonents, 10 open vowels, and 145 rimes.

Instead of separate radicals used as diacritics to represent tone, distinct tonal rimes are included among the set of 145, but the basic principle of using sinographic radicals to represent initials and rimes, and then combining them into square graphemes that mimic Hán (or Nôm) writing remains the same. The author, Nguyễn Khắc-tỏan, also includes a preface written solely in Quốc Ngũ Vietnamese, which identifies the narrowly aesthetic purpose of the script:

The graphs of this style are all Chinese characters bearing excellent meanings, yet also render rimes and are capable of translating 16,238 sounds, just as the letters of Quốc Ngũ. [My] intention is for them to be used to write parallel couplets conveniently.

my translation; NGUYỄN, 1

14 “Thứ nôm mới này là thứ chữ chơi ... Viết phải dùng bút lòng thì chữ mới đẹp." 


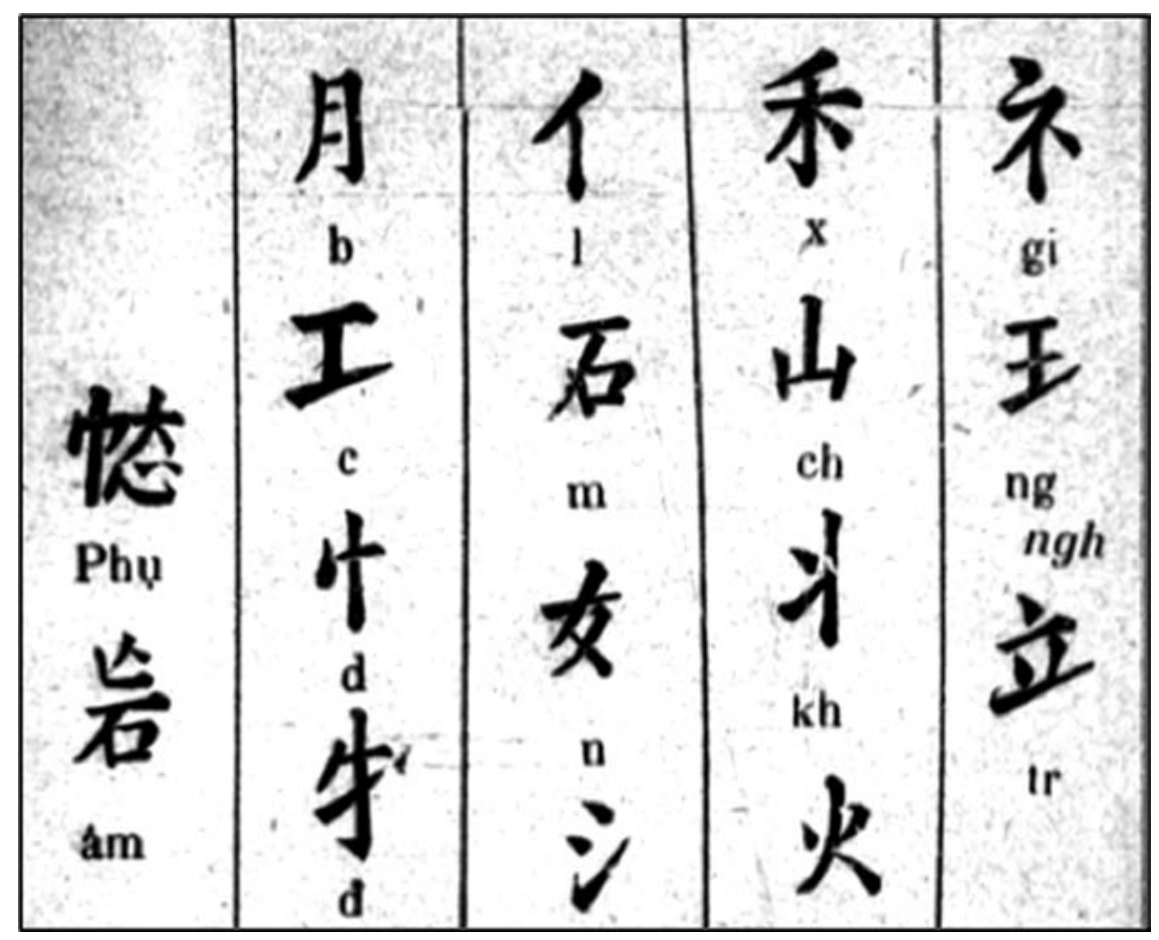

FIGURE 3 Sinographic radicals used for initial consonants in A Sinitic-style Quốc Ngũ

Chữ cái lối chữ này toàn chữ nho có nghĩa hay, cũng đánh vần và cũng dịch được 16.238 tiếng như chữ quốc-ngữ, mục đích dùng để viết câu đối cho tiện.

Compare this narrow practicality with the reverence for sinographic writing expressed in the Explication of the Guide to Jeweled Sounds, Tôn Thất Tồ's impassioned defense of Chinese characters, the technical discussion in Viet Characters (1929), or even the discussion of Vietnamse cultural habits in New Chũ Nôm (1932). The selling point of this script, like New Chũ Nôm, is that it maps easily on to Quốc Ngữ but as if to one-up his competitor, Nguyễn Khắctoản even claims that "anyone who knows Quốc Ngũ can understand [this script] after examining it for just a few hours" (Nguyễn K.-T., p. I). ${ }^{15}$

15 The two books were both printed in Nam Định at what appears to be the same publishing house (Mỹ Thắng). 


\section{Dissolving Scriptworlds?}

Each of the texts discussed briefly in this article expresses an evolving statement on what could be called the "language ethics" of Vietnamese literati, from the overtly sinocentric values of the 1641 Explication of the Guide to Jeweled Sounds (echoed in Tôn Thất Tổ's 1918 protest to Emperor Khải Định), to the narrowly aesthetic intentions of the 1933 Viet Characters: Quốc Ngũ displayed in Chinese Characters. ${ }^{16}$ When examined together, these texts articulate a secularization of the concept of $v a ̆ n$ and its relationship to the written sign, occurring rapidly over the late 1920s-30s. Again, a striking parallel may be drawn with the Turkish debates of the same period. In 1926, Kiliçzade Hakki argued that the sacred nature of the Quran did not apply to the Arabic alphabet, in an article dryly entitled "Gabriel didn't bring the Arabic letters too, you know" (Lewis,

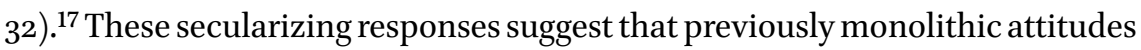
on script and culture were forcibly readjusted in a multi-literate and increasingly globalized world.

But does this process of secularization describe both the "exit" from a sinographic scriptworld as well as the "entry" into a latinized scriptworld? Did the adoption of a latinized script lead to the same kind of defining cultural paradigms that the initial adoption of sinographic writing had? What would a vernacularized, literate society's "entry" into a new scriptworld actually mean? It is tempting to aggrandize the adoption of the alphabet into a kind of broad westernization of Vietnamese culture - not least of which because that kind of rhetoric was often used either to justify or condemn it. In response to Tôn Thất Tổ's vehement defense of Chinese characters discussed above, Emperor Khải Định (r. 1916-1925) painted a sweeping vision of the road to modernity, paved with French letters:

We have discussed this many times already; they (erudites of the court) trepidatiously dither and speak endlessly, and yet in the end still hear nothing. If the Treasured Protectorate wishes to abandon Chinese characters, it is for three reasons. First, although from youth, the people of our nation study the books of the Worthies and Sages, yet when grown,

16 As discussed in note 11, the views of the 1641 Explication were also powerfully expressed in the 1921 New Characters for the Nation's Sounds.

17 This article was written in response to proponents of the Arabic-Persian alphabet. As Lewis notes, this rejoinder was not entirely fair, since it ignored a major argument of those defending the Arabic-Persian script — that literacy in the Quran would plummet if the Latin alphabet were adopted (see Lewis Turkish 32 ). 
they do the opposite, and in terms of logic contradict each other. Secondly, today is an era of communication, and French letters are a form of script both fine and commonly used. In abandoning Chinese characters, students will focus wholeheartedly on French letters, making it easier for communication thereafter. Thirdly, [when] the people of our nation only and wholeheartedly study French letters, and thinking is already focused on the thorough and deep, then standards will certainly improve very swiftly, so that our future will spread out, beat its wings and fly to the high peak of civilization. Our Vietnam, like the whole realm of the Eastern Seas, ${ }^{18}$ is becoming a small France; [is this not] simply excellent and beautiful?

my translation; NGUY ỄN, $355 \cdot{ }^{19}$

Cũng đã thương lượng nhiều lần rồi, chỉ e ra rả nói mãi mà rồi họ vẫn bỏ ngoài tai. Quí Bảo hộ sở dĩ muốn bỏ chữ Hán là bởi có ba nguyên nhân. Thứ nhất là mặc dù người nước ta từ nhỏ đã đọc sách Thánh hiền ... nhưng khi lớn lên lại làm ngược lại, về nghĩa lí trái ngược nhau; Thứ hai là ngày nay là thời đại giao thiệp, chữ Pháp là thứ chũ̃ vừa tinh vừa thông dụng. Bỏ chữ Hán đi học trò sẽ chuyên tâm vào chũ Pháp, dễ dàng cho sự giao thiệp sau này; Thứ ba là người nước ta chỉ còn chuyên tâm học chữ Pháp, tư tưởng đã tập trung chuyên sâu thì trình độ ắt tiến bộ rất nhanh để tương lai phơi phởi vỗ cảnh bay tới đỉnh cao của sự văn minh. Việt Nam ta cũng như cả cõi Đong Dương trở thành một nước Pháp con há chẳng tốt đẹp hay sao.

It is difficult to ignore the overtly pro-colonial language here. However, the basic logic of the Emperor's edict - that French letters lead to French knowledge, which unlocks a broader world and paves the way to modernization (in France's image) - was shared even by anticolonial intellectuals striving for independence. ${ }^{20}$

18 Here, the Indochinese Peninsula.

19 At the time of writing, I was unable to access the original (Literary Sinitic) text, currently stored at the Paris archives of the École française d'Extrême-Orient. Thus, my translations are based on Nguyễn Văn Nguyên's translation into Vietnamese, published in 2010.

20 Note the conflation of language and writing committed by Khải Định in expressing these sentiments. In many places, writers refer to "chũ Pháp" (French letters) but seem in reality to mean the French language, and more broadly, French learning. This is similar to Tôn Thất Tổ's use of "Chinese characters" to refer both to sinographic writing and Literary Sinitic learning in general. Please see the full version of this article for a discussion of 
Yet Emperor Khải Định's very appropriation of script as a symbol of culture suggests a fluidity of language ethics that presupposes any truly exclusive membership in a new scriptworld. Note, for instance, that the Emperor closes his arguments with an appeal to move slowly on the transition, in order to safeguard the body of knowledge and culture represented in sinographic writings:

Nevertheless, in terms of ideology, our nation has revered and esteemed Chinese learning for a long time, and ancient texts and scriptures are many. The time in which ancient books have been able to be translated into Quốc Ngữ and French letters, to date has not amounted to many years, and thus Chinese characters may not be abolished hastily.

my translation; NGUYỄN, 356

Tuy nhiên, xét về lí thì nước ta vốn sùng chuộng Hán học đã lâu, thư tịch cổ rất nhiều ... trong khi sách cổ được dịch ra chữ Quốc ngữ và chữ Pháp hiện chẳng được bao Năm, nên chũ Hán không thể mau chóng phế bỏ đi được.

Not even Khải Định, who gained notoriety as a mouthpiece for the colonial regime, imagined the adoption of the alphabet as requiring any kind of radical abandonment of Vietnamese culture, literature, or philosophy - steeped as they were in a sinographic heritage. ${ }^{21}$ Though the Emperor viewed the alphabet as a passport to European civilization, he did not associate the abandonment of sinographic writing as the eradication of traditional culture, since the canon of sinographic knowledge could be translated and/or transliterated where necessary. ${ }^{22}$ All that was needed was time. The Emperor thus foreshadows a secularized view of script that rejected, whether intentionally or not, a concept of $v a ̆ n$ underpinning the practice of writing. Crucially, this secularized view (which as we have already seen ultimately wins out) permits a diversity of script practices, where belief in the cosmological significance of the sinograph demanded one true form of writing (or the endless struggle to recapture it). Tôn Thất Tổ probably found this edict appalling. Yet, as predicted by Khải Định, one of the major

the confusion of scripts and languages, as well as a comparison with relevant processes of modernization and script/language reform in contemporary China.

21 In this way he was quite measured in his arguments to abandon sinographic writing (see previous note).

22 It is likely that this rhetoric was designed to appease opposing factions at court. However, the politics behind the statement do not affect the point that such an argument was conceivable at the time. 
literary preoccupations of the next few decades was the translation of Literary Sinitic texts, and the transliteration of vernacular Chũ Nôm texts into Vietnamese Quốc Ngữ. ${ }^{23}$ This occurred alongside numerous translations of French, English, Russian, and Japanese texts into Vietnamese as well. Thus, the adoption of the alphabet failed to insulate Vietnamese culture within a latinized circuit of literature, but rather fostered productive industries of translation and transliteration. ${ }^{24}$

In other words, the adoption of a latinized alphabet may have signaled Vietnam's emergence from an insulated sinographic scriptworld, but it did not really herald her entry into a similarly insular Latin scriptworld. Rather, this transition, like many processes of modernization, involved the dismantling of a set of perceived cultural paradigms - in this case, the importance of văn as it related to the practice of writing. The adoption of a new script by an already literate Vietnamese society meant the broadening of modes of cultural transfusion, not the swapping of one mode for another. Thus, the intellectual secularization of sinographic writing described in this article, seems to suggest a breakdown in the importance of scriptworld boundaries, and ultimately, the dissolving of cultural imperatives founded on the form and figure of writing.

In conclusion, the Vietnamese case suggests that a concept of "scriptworlds" must account for the singularity of a culture's initial experience of literacy, and especially the role played by diglossia in the secondary development of a vernacular tradition. In subsequent script adaptations, while the form of writing may be treated as a symbol of culture, it does not appear to determine cultural transfusion in the same manner as initial experiences of writing may. The precedent of diglossic literacy, and the adaptation of one script designed for one language to represent another, seems to engender an awareness of the promiscuity of language and writing - which in turn, naturally

23 For more on these activities and their relationship to the end of colonial power in Vietnam, see David Marr (1981), Vietnamese Tradition on Trial; Hue-tam Ho Tai (1992), Radicalism and the Origins of the Vietnamese Revolution; and Shawn McHale (2004), Print and Power: Confucianism, Communism, and Buddhism in the Making of Modern Vietnam.

24 Certainly, the rapid abandonment of training in Literary Sinitic language, as well as Chũ Nôm script, did result in some losses. Indeed, by the second half of the 2oth century, the number of people trained to read Nôm plummeted to only a handful worldwide, and Nôm literature (often a low priority for translation) did suffer from a great lack of attention for decades. However, this neglect of Nôm literature was perhaps due more to a reverence for Literary Sinitic (over vernacular Vietnamese), than any francocentric opprobriation of sinographic literature. 
leads to a dilution of the capacity for script to determine cultural diffusion. The secularization of the sinograph in 1920s Vietnam suggests a pruning of cultural values inconsistent with an increasingly "heteroglossic" — and indeed, heterographic - world. One potential counterexample might be found in the spread of the Arabic alphabet to previously literate cultures; though in these cases, I would again question whether or not processes of cultural transformation were truly driven or determined by script. The case of Egypt might be particularly interesting to examine. In any case, the correlation may be scalar. Finally, the effect of modernity on scriptworlds seems particularly solvent. Future work on the concept of "scriptworlds" should not only compare cases of initial, diglossic literacy (such as the Akkadian adoption of Cuneiform or the Thai adoption of a Cambodian Pallava script) versus secondary or tertiary script adoption, but should also investigate the special role that modernization, and an increasingly interconnected and global experience, may play in the erosion of scriptworlds, and the dismantling of their walls.

\section{Works Cited}

Damrosch, David. "Scriptworlds: Writing Systems and the Formation of World Literature." Modern Language Quarterly 68: 2 (2007), 195-219.

Boltz, William G. The Origin and Early Development of the Chinese Writing System. New Haven: The American Oriental Society, 1994.

DeFrancis, J. Colonialism and Language Policy in Vietnam. The Hague: Mouton, 1977.

Lewis, G. The Turkish Language Reform: A Catastrophic Success. Oxford: Oxford UP, 1999 .

Lurie, D. Barnett. Realms of Literacy: Early Japan and the History of Writing. Cambridge, Mass.: Harvard University Asia Center, 2011.

McHale, S. Frederick. Print and Power: Confucianism, Communism, and Buddhism in the Making of Modern Vietnam. Honolulu: University of Hawai'i Press, 2004.

Marr, D. Vietnamese Tradition on Trial: 1920-1945. Berkeley: University of California Press, 1981.

Nguyễn, K.-C. Chũ Nôm Mới (New Chũ Nôm). Nam Định: Imprimerie My-Thang, 1932.

Nguyễn, K.-T. Chũ̃ Việt, Quốc-Ngũ̃ lối chũ nho (Viet Characters, Quốc Ngũ Displayed in Chinese Characters). Nam Định: Mỹ-Thắng ấn quán, 1933.

Nguyển Văn Nguyên, translator. Đồng Khánh, Khải Định chính yếu (Essential Writings of Emperors Đồng Khánh and Khải Định). Hanoi: Thời Đại publishing, Center for East-West Culture \& Language, 2010.

Phạm, H.-H. "Việt-nam ta biết chữ Hán từ đời nào?" ("from what Era Has Our Vietnam Known Chinese Characters?”). Nam Phong 5-29 (1919), 416-419. 
Phan, J.D. Lacquered Words: The Evolution of Vietnamese under Sinitic Influences from the 1st Century BE through the 17th Century CE. Ithaca, NY: Cornell University, 2013.

Phan, J.D. "Chũ Nôm and the Taming of the South: A Bilingual Defense of Vernacular Writing in the Chỉ Nam Ngọc Âm Giải Nghĩa." Journal of Vietnamese Studies 8: 1 (2013), 1-33.

Phan, J.D. "Rebooting the Vernacular in Seventeenth-Century Vietnam." In Rethinking East Asian Languages, Vernaculars, and Literacies, 1000-1919, ed. B.A. Elman. Leiden: Brill, 2014, 96-128.

Pollock, S.I. The Language of the Gods in the World of Men: Sanskrit, Culture, and Power in Premodern India. Berkeley: University of California Press, 2006.

Roland, J., Uson, R., \& Uson, M. Portuguese Pioneers of Vietnamese Linguistics before 1650. Bangkok: Orchid Press, 2002.

Tai, H.T.H. Radicalism and the Origins of the Vietnamese Revolution. Cambridge: Harvard UP, 1992.

Vi, H. Đ. (1929). Việt Tư: Một lối việt tiếng An-Nam (Viet Characters: A Style of Writing Annamese). Haiphong.

Wilcox, W. "The Examination System under the French Protectorate: A Tool for French Control or Vietnamese Protest?" The International Workshop, "Literature of High Stakes and Long Odds: Locating Civil Service Eamination Writings in the Late Imperial Cultural Landscape." Boston, MA: University of Massachusetts Confucius Institute. 17 Nov. 2002. Conference Paper. 